\title{
ERK1/2 Inhibitor KO-947
}

National Cancer Institute

\section{Source}

National Cancer Institute. ERK1/2 Inhibitor KO-947. NCI Thesaurus. Code C141074.

An inhibitor of the extracellular signal-regulated kinases (ERK) 1 and 2, with potential antineoplastic activity. Upon intravenous administration, KO-947 specifically binds to and inhibits both ERK 1 and 2, thereby preventing the activation of mitogen-activated protein kinase (MAPK)/ERK-mediated signal transduction pathways. This results in the inhibition of ERK-dependent tumor cell proliferation and survival. The MAPK/ERK pathway is often upregulated in a variety of tumor cell types and plays a key role in the proliferation, differentiation and survival of tumor cells. 